Article

\title{
Comparative Study of CDST \& Multiplex PCR to Detect MBL Producing Gram-Negative Bacilli among VAP Patients Admitted in a Public Medical College Hospital of Bangladesh
}

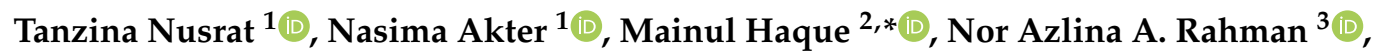 \\ Arup Kanti Dewanjee ${ }^{4}\left(\mathbb{D}\right.$, shakeel Ahmed ${ }^{5}$ (D) and Diana Thecla D. Rozario ${ }^{6}$ (D) \\ 1 Department of Microbiology, Chattogram Medical College, Chattogram 4217, Bangladesh; \\ tanzina.nusrat@gmail.com (T.N.); nasima196177@yahoo.com (N.A.) \\ 2 Unit of Pharmacology, Faculty of Medicine and Defence Health, Universiti Pertahanan Nasional \\ Malaysia, (National Defence University of Malaysia), Kem Sungai Besi, Kuala Lumpur 57000, Malaysia \\ 3 Department of Basic Health, Kulliyyah of Allied Health Sciences, International Islamic University Malaysia, \\ Jalan Sultan Ahmad Shah, Bandar Indera Mahkota, Kuantan 25200, Malaysia; nazara@iium.edu.my \\ 4 Department of Microbiology, Marine City Medical College, Chattogram 4217, Bangladesh; \\ arupdewanjee@yahoo.com \\ 5 Department of Microbiology, Bangladesh Institute of Tropical \& Infectious Diseases, Chattogram 4217, \\ Bangladesh; shakeelcmc@gmail.com \\ 6 Department of Microbiology, Colonel Malek Medical College, Manikgonj 6700, Bangladesh; \\ dianadrozario17@yahoo.com \\ * Correspondence: runurono@gmail.com
}

Received: 6 August 2019; Accepted: 9 September 2019; Published: 12 September 2019

\begin{abstract}
Background: Ventilator-associated pneumonia (VAP) is the most common nosocomial infection in intensive care units (ICU), which accounts for $25 \%$ of all ICU infection. Documenting carbapenem-resistant gram-negative bacilli is very important as these strains may often cause outbreaks in the ICU setting and are responsible for the increased mortality and morbidity or limiting therapeutic options. The classical phenotypic method cannot provide an efficient means of diagnosis of the metallo- $\beta$-lactamases (MBLs) producer. Polymerase chain reaction (PCR) assays have lessened the importance of the phenotypic approach by detecting metallo- $\beta$-lactamase resistance genes such as New Delhi metallo- $\beta$-lactamase (NDM), Imipenemase (IMP), Verona integron-encoded metallo- $\beta$-lactamase (VIM), Sao Paulo metallo- $\beta$-lactamase (SPM), Germany Imipenemase (GIM). Objective: To compare the results of the Combined Disc Synergy Test (CDST) with that of the multiplex PCR to detect MBL-producing gram-negative bacilli. Materials and Method: A total of 105 endotracheal aspirates (ETA) samples were collected from the ICU of a public school in Bangladesh. This cross-sectional study was carried out in the Department of Microbiology, Chittagong for quantitative culture, CDST test, and multiplex PCR for bla $\mathrm{IMP}_{\mathrm{IM}}$, bla $\mathrm{VIM}_{\mathrm{IM}}$, bla $\mathrm{N}_{\mathrm{NDM}}$ genes of MBL producers. Results: Among the 105 clinically suspected VAP cases, the quantitative culture was positive in 95 (90\%) and among 95 g-negative bacilli isolated from VAP patients, 46 (48.42\%) were imipenem resistant, 30 (65.22\%) were MBL producers by CDST, 21 (45.65\%) were identified as MBL producers by multiplex PCR. Conclusion: PCR was highly sensitive and specific for the detection of MBL producers.
\end{abstract}

Keywords: VAP; MBL; multiplex PCR; metallo- $\beta$-lactamases; CDST test; bronchoalveolar lavage; BAL 


\section{Introduction}

VAP is defined as pneumonia occurring after the first $48 \mathrm{~h}$ of starting mechanical ventilation $[1,2]$. VAP is often correlated with an extension of the duration of hospital stay that necessitates Intensive Care Unit (ICU), mechanical ventilation (MV), subsequently, increasing healthcare overheads and mortality [2,3]. The VAP related mortality rate varies from $20-75 \%$ [4]. The documentation of the causative microorganism of VAP and their antimicrobial sensitivity is the fundamental issue for the overall treatment planning and to ensure better treatment outcome $[5,6]$. Protected specimen brush (PSB) or bronchoalveolar lavage (BAL), or open-lung biopsy, have been established in detecting VAP contributory microorganisms and commonly measure higher values than endotracheal aspirates (ETA) $[7,8]$. The ETA gram-staining, nonquantitative, and semiquantitative culture method is dependable and reliable requiring small procedural proficiency but no specific apparatus $[8,9]$. Quantitative ETA culture (QETAC) is a non-invasive method that is cheaper than quantitative BAL fluid culture, and QETA has the potential to substitute for BAL in quantitative cultures [10]. The optimum level frequently embraced for detecting and establishing pneumonia by quantitative cultures are $\geq 10^{5}$ to $10^{6}, 10^{4}$, and $10^{3} \mathrm{CFU} / \mathrm{mL}$ for QETAC, bronchoscopic BAL, and PSB, correspondingly, with $10^{5} \mathrm{CFU} / \mathrm{mL}$ being the most extensively recognized value $[7,9,11,12]$. The emergence of antimicrobial resistance infection is becoming a significant health problem worldwide, especially in healthcare-associated infections (HCAIs) [2,13]. Carbapenem-resistant gram-negative bacilli are very important as these strains frequently cause outbreaks in the ICU setting and are responsible for the increased mortality and morbidity and limit therapeutic options [14,15]. Carbapenemase, namely the New Delhi MBLs, are producing microorganisms emerging rapidly throughout the globe and leading to enormous public health threat $[16,17]$. Rapid detection of these MBLs is necessary to institute appropriate treatment and effective infection control measures [17,18]. The classical phenotypic method cannot provide an efficient means of diagnosis of MBL producers because most of the atypical bacteria grow either slowly or not in culture, leading to delays in the detection and diagnosis $[19,20]$. Multiplex PCR assays able to detect MBL resistance genes, such as the NDM, IMP, VIM, SPM, GIM, consequently, the importance of the old-age classical phenotypic method was reduced in medical science [21,22]. MBLs are rapidly emerging resistance elements among Pseudomonas aeruginosa and other gram-negative pathogens [23]. Individually, the MBL gene is situated on precise genetic elements, including integrons, transposons, plasmids, or on the chromosome, in which they transmit genes encoding factors of resistance to carbapenems and other antibiotics, pondering multidrug resistance [24]. After that, the proper diagnosis of causative microorganisms is essential.

This study was designed to detect causative microorganism VAP. Initially, isolation and identification of gram-negative bacteria by quantitative culture methods was performed and the determination of MBL-producing bacteria by phenotypic methods (CDST) and the confirmation of MBL genes by multiplex PCR.

\section{Objectives of the Study}

To compare the results of CDST with that of the multiplex PCR to detect MBL-producing gram-negative bacilli.

\section{Materials and Methods}

Study design, place period, and population: This cross-sectional study was conducted in the department of Microbiology of Chattagram Medical College from July 2017 to June 2018. A total of 105 suspected VAP patients admitted to the ICU of Chattagram Medical College Hospital (CMCH) of age as ranging from 5 to 75 years were included in the study. Sample selection: The patients who had mechanical ventilation by endotracheal tube for more than $48 \mathrm{~h}$ along with two or three of the following criteria suggesting VAP: (i) Fever/hypothermia or leukocytosis/leucopenia; (ii) Purulent tracheal discharge; (iii) Positive chest $\mathrm{X}$-ray (chest X-ray shows consolidation or infiltration or pleural 
effusion) were included in the study. Patients who had severe hypoxemia $\left(\mathrm{PaO}_{2} / \mathrm{FiO}_{2}<100\right)$, immunocompromised, or neutropenic symptoms were excluded from the study. The selection criteria were based on the earlier published study [25]. Data collection: Data was collected, recorded, edited, and analyzed in a predesigned datasheet. Statistical analysis: The results of the experiments were recorded and analyzed systematically using descriptive analysis. The diagnostic values of CDST against PCR as the gold standard (sensitivity, specificity, predictive values, accuracy, and their $95 \%$ confidence interval (CI)) were analyzed using MEDCALC ${ }^{\circledR}$, an online software [26]. SPSS Software (IBM Corp. Released 2016. IBM SPSS Statistics for Windows, Version 24.0. IBM Corp.: Armonk, New York, NY, USA) was used to analyze the comparability of the two tests using McNemar's test for dependent variables. The significance value was set to 0.05 . Ethical approval: This study obtained ethical approval from Chattagram Medical College, Chattagram, Bangladesh (Reference No.: CMC/PG/2017/322, Date: 04-05-2017).

\section{Laboratory Method}

This study intended to identify bla $\mathrm{IMP}_{\mathrm{IM}}$, $\mathrm{bla}_{\mathrm{NDM}}$, and the bla $\mathrm{VIM}_{\mathrm{M}}$ genes of $\beta$-lactamase producing gram-negative bacteria. A total of 105 ETA samples were collected by mucus extractors in a sterile capped container and immediately brought to the laboratory. Standard methods were used for the analysis and culture of ETA specimens collected from all suspected patients. Immediately after receipt, one $\mathrm{mL}$ of ETA was diluted to a final concentration of 1:100 in sterile phosphate buffer solution. After being manually stirred, a sample was taken with the help of $0.01 \mathrm{~mL}$ calibrated loop and was cultured on 5\% sheep blood agar and chocolate agar, and MacConkey's agar plates then incubated in $5 \% \mathrm{CO}_{2}$ at $35^{\circ} \mathrm{C}$ for $48-72 \mathrm{~h}$. The cut-off point for the ETA was $10^{5}-10^{6} \mathrm{cfu} / \mathrm{mL}$ for the quantitative culture. All isolates were identified based on their colony morphology, culture characteristics, and biochemical reactions according to the standard microbiological procedures. The imipenem resistant screening test was performed by the Kirby-Bauer disc diffusion test. The media used was Mueller-Hinton Agar Media, the potency of the imipenem disc was $10 \mu \mathrm{g}$. The standard values determined by the National Committee for Clinical Laboratory Standards (NCCLS) pathogens were classified as sensitive $(21 \mathrm{~mm})$, intermediate resistant $(16-20 \mathrm{~mm})$, and resistant $(15 \mathrm{~mm})[27,28]$ and a zone of inhibition of $\geq 20 \mathrm{~mm}$ was considered sensitive, a zone of inhibition less than $20 \mathrm{~mm}$ was considered resistant to Imipenem [29]. All the imipenem-resistant Pseudomonas, E. coli, Klebsiella, and Acinetobacter, were tested for detection of MBLs by Imipenem-EDTA CDST. ETA was preserved at $-70^{\circ} \mathrm{C}$ for DNA extraction. Test organisms were inoculated onto plates with Muller-Hinton agar as recommended by CLSI, 2019. Two $10 \mu \mathrm{g}$ imipenem discs (Becton Dickinson, Franklin Lakes, NJ, U.S.) were placed on the plate, and appropriate amounts of $10 \mu \mathrm{l}$ of Ethylenediaminetetraacetic acid (EDTA) solution was added to one of them to obtain the desired concentration $(750 \mu \mathrm{g})$. The inhibition zones of the imipenem and imipenem-EDTA discs were compared after 16 to $18 \mathrm{~h}$ of incubation at $37^{\circ} \mathrm{C}$. In the Combined Disc Test, the increase in the inhibition zone with the imipenem and EDTA disc was $>7 \mathrm{~mm}$ than the imipenem disc alone, it was considered as MBLs positive [30-34]. The PCR assay was performed on culture isolates using the specific primers to detect the blaIMP, blaIMP, and blaNDM genes $[35,36]$. DNA from imipenem-resistant culture isolates was extracted according to the GeneJet DNA extraction kit (ThermoFisher Scientific, Waltham, MA, USA). Primer sequence used for amplification was blaIMP (F: GGAATAGAGTGGCTTAAYTCTC, R: GGTTTAAYAAAACAACCACC), blaVIM (F: GATGGTGTTTGGTCGCATA, R: CGAATGCGCAGCACCAG), blaNDM (F: GGTTTGGCGATCTGGTTTC, blaNDM-R: CGGAATGGCTCATCACGATC) [37]. The composition of the PCR Master Mix was $0.05 \mathrm{U} / \mu \mathrm{L}$ TaqDNA polymerase; reaction buffer was $4 \mathrm{mM} \mathrm{MgCl2}, 0.4 \mathrm{mM}$ of each dNTP (dATP, dCTP, dGTP, dTTP) (ThermoFisher Scientific, Waltham, MA, USA). The final reaction volume was $50 \mu \mathrm{L}$. The amplification (PCR) was performed in a thermal cycler (Eppendorf AG, Hamburg, Germany). The protocol of thermal cycles of PCR for the detection of the genes included the initial denaturation at $95^{\circ} \mathrm{C}$ for $3 \mathrm{~min}-1$ cycle, denaturation at $95{ }^{\circ} \mathrm{C}$ for $30 \mathrm{~s}$, primer annealing at $55^{\circ} \mathrm{C}$ for $30 \mathrm{~s}$, extension at $72{ }^{\circ} \mathrm{C}$ for $20 \mathrm{~s}-35$ cycles, final extension at $72{ }^{\circ} \mathrm{C}$ for $10 \mathrm{~min}-1$ 
cycle (ThermoFisher Scientific, Waltham, MA, USA). The final amplified products were subjected to electrophoresis on $1.5 \%$ agarose gel. The presence of the bla $\mathrm{IMP}-232, \mathrm{bla}_{\mathrm{VIM}}-390$, and $\mathrm{bla}_{\mathrm{NDM}}-621$ band under UV transilluminator showed positive results.

\section{Results}

A total of 105 clinically suspected VAP cases were enrolled in this study from $\mathrm{CMCH}$. The mean age of the patients was $51.53 \pm 18.81$ years. Ninety-five $(90 \%)$ clinically suspected VAP cases were positive for the quantitative culture method (Figure 1$)$. The highest number $(30,31.58 \%$ ) of culture-positive cases were in the age group of 66 to 75 years (Table 1). Among the 95 culture-positive cases, $69(72.63 \%)$ were male, and $26(27.37 \%)$ were female where the male-female ratio was 2.65:1. MBL- producing gram-negative bacteria were identified by the imipenem-resistant screening test (Table 2). Among 95 gram-negative bacilli isolated from VAP patients, 46 (48.42\%) were imipenem resistant. Out of the 46 IMP-screened positive cases, 23 (56.1\%) were Acinetobacter spp. followed by $13(54.17 \%)$ Klebsiella spp., 6 (33.33\%) Pseudomonas spp., 3 (33.33\%) E. coli, and one (25\%) Proteus spp. Out of the 46 imipenem-resistant positive gram-negative bacteria, 30 (65.22\%) were MBL-producers by CDST (Figure 2). Twenty-one (45.65\%) were identified as MBL-producers by multiplex PCR (Figures 3 and 4 ). Snapshots showing the multiplex PCR show gel electrophoresis of amplified DNA of bla IMP $_{\text {and }}$

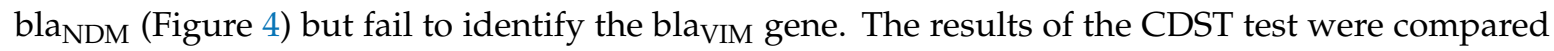
with PCR as the gold standard by Chi-square tests (Table 3). The difference between the CDST and PCR to detect MBL-producers was statistically significant $(p<0.05)$.

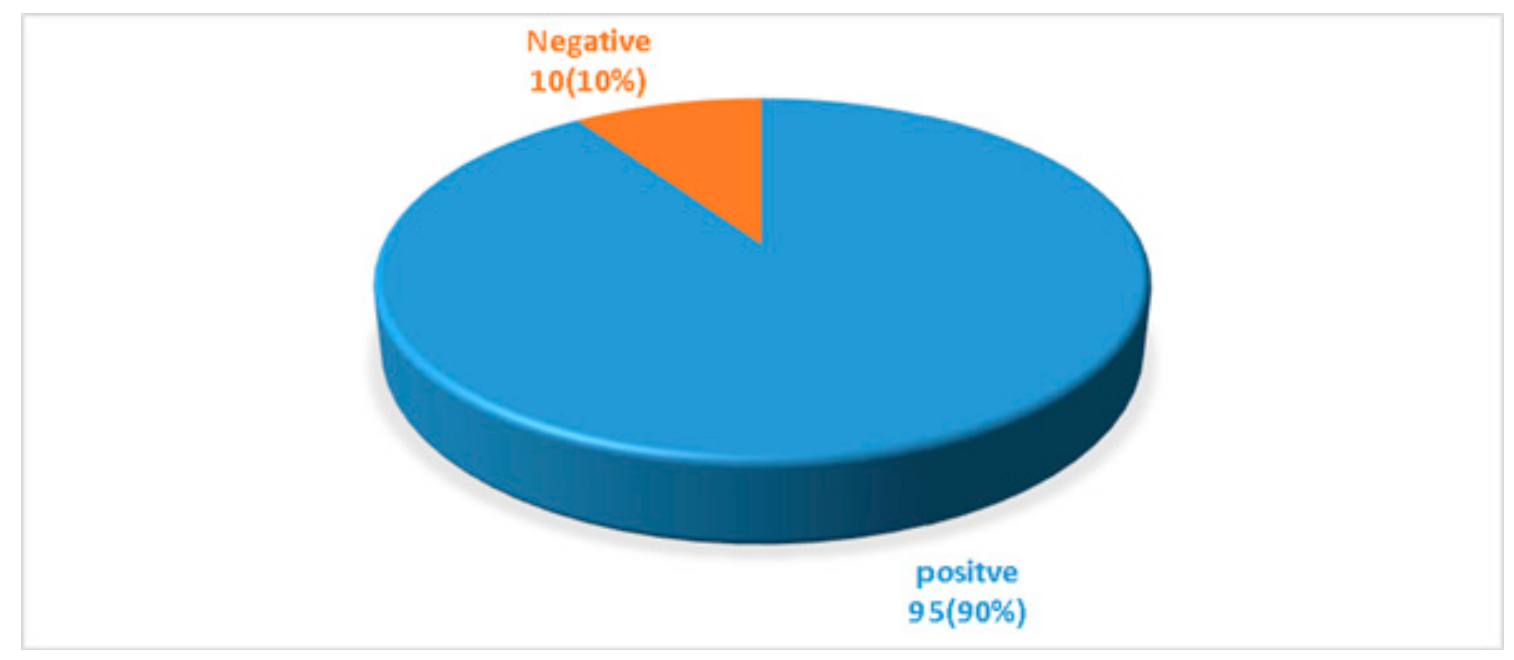

Figure 1. Pie Chart is showing the rate of isolation of bacteria from clinically suspected VAP cases by quantitative culture. Total cases $=105$.

Table 1. Age and Sex distribution of culture-positive VAP cases $(n=95)$.

\begin{tabular}{cccc}
\hline \multirow{2}{*}{ Age Group (Years) } & \multicolumn{2}{c}{ Sex (\%) } & \multirow{2}{*}{ Suspected VAP Cases } \\
\cline { 2 - 3 } & Male & Female & 4 \\
\hline $5-15$ & 3 & 1 & 9 \\
$16-25$ & 5 & 4 & 10 \\
$26-35$ & 6 & 4 & 7 \\
$36-45$ & 6 & 1 & 15 \\
$46-55$ & 11 & 4 & 20 \\
$56-65$ & 18 & 2 & 30 \\
$66-75$ & 20 & 10 & 95 \\
Total & $69(72.63 \%)$ & $26(27.37 \%)$ & \\
\hline
\end{tabular}

Male: Female $=2.65: 1$. Mean $\pm \mathrm{SD}=51.53 \pm 18.81$ 
Table 2. The distribution of MBL-producing gram-negative bacilli by the imipenem-resistant screening test $(n=95)$.

\begin{tabular}{ccc}
\hline \multirow{2}{*}{ Name of the Organism } & \multicolumn{2}{c}{ Imipenem-Resistant Screening Test (\%) } \\
\cline { 2 - 3 } & Positive & Negative \\
\hline Acinetobacter spp. (41) & $23(56.1)$ & 18 \\
Klebsiella spp. (24) & $13(54.17)$ & 11 \\
Pseudomonas spp. (18) & $6(33.33)$ & 12 \\
E. coli (9) & $3(33.33)$ & 6 \\
Proteus spp. (4) & $1(25)$ & 3 \\
Total & $46(48.42)$ & $49(51.60)$ \\
\hline
\end{tabular}

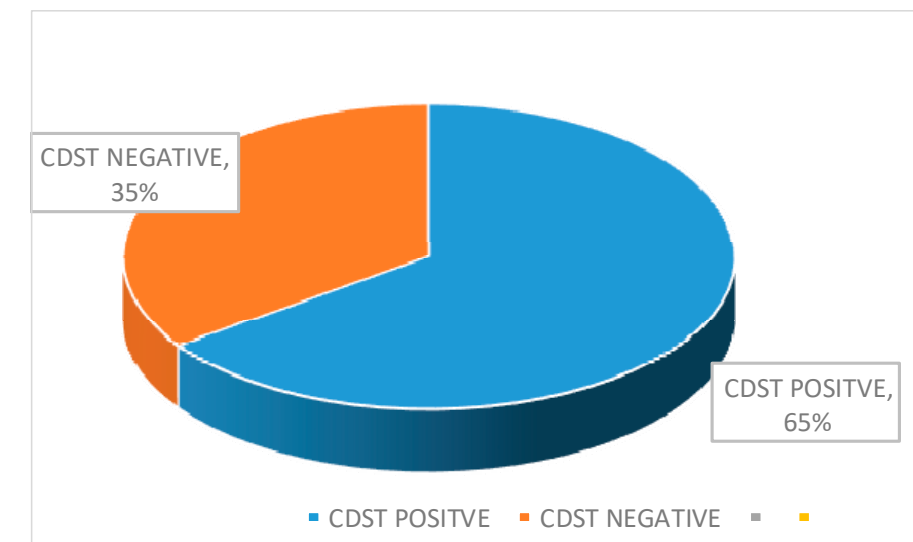

Figure 2. Pie chart showing the rate of detection of MBLs producing gram-negative bacilli by CDST.

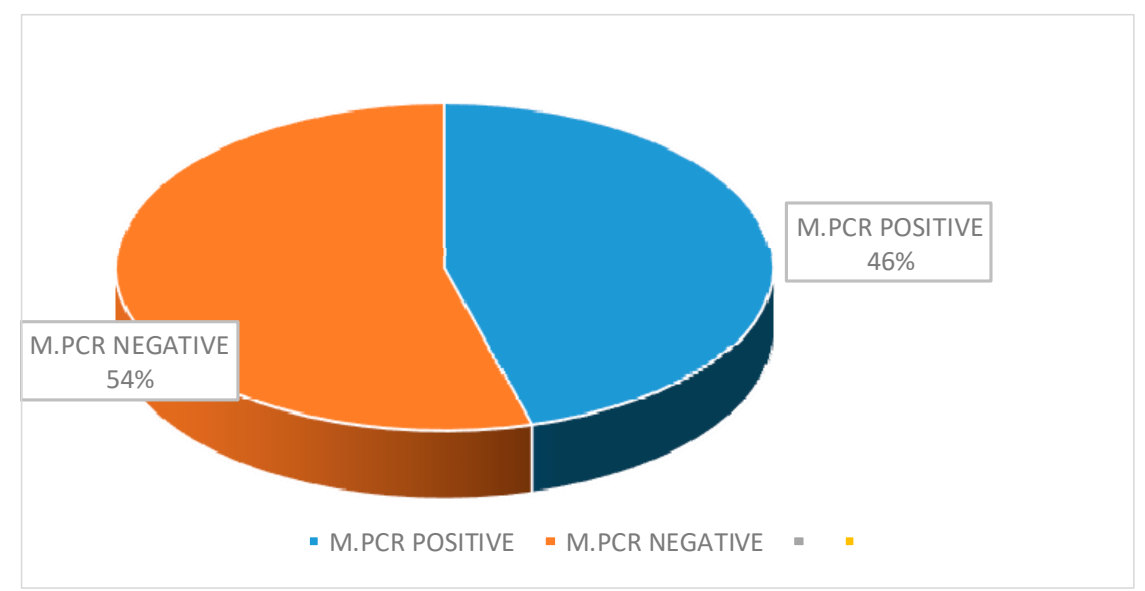

Figure 3. Pie chart showing the percentage of detection of MBLs producing gram-negative bacilli by multiplex PCR.

Table 3. Comparison of CDST and multiplex PCR considering multiplex PCR as the gold standard ( $\mathrm{n}=46$ ).

\begin{tabular}{cccccc}
\hline \multirow{2}{*}{} & \multirow{2}{*}{ Test } & & \multicolumn{2}{c}{ PCR } & \multirow{2}{*}{ Total } \\
\cline { 3 - 4 } & & Positive & Negative & \\
\hline \multirow{3}{*}{ CDST } & Positive & 18 & 12 & 30 \\
& & Negative & 3 & 13 & 16 \\
& \multirow{2}{*}{ Total } & & 21 & 25 & 46 \\
\hline
\end{tabular}

$\mathrm{X} 2$ value $=7.1 . p<0.05$. 


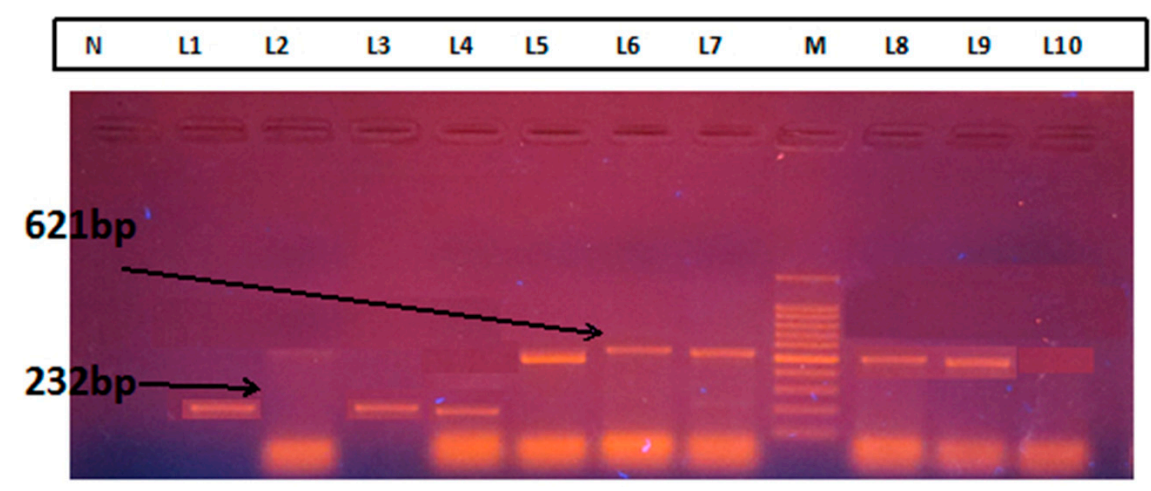

Figure 4. Snapshot is showing multiplex PCR gel electrophoresis of amplified DNA. N-Negative Control, M-DNA ladder, L1,3,4-showing a positive band of the bla IMP gene, L5,6,7,8,9-indicating a definite band of the bla NDM gene, L2-no gene detected, L10-is the positive control.

Table 4 shows the diagnostic values of CDST against PCR as the gold standard. The sensitivity (true positive rate) was quite high $(85.7 \%)$ due to high positive rates of CDST, but unfortunately, this leads to high false-positives leading to lower specificity (true negative rate, $52.0 \%$ ). With the accuracy of $67.4 \%$, the McNemar's test performed showed a significant difference between the results of CDST and PCR with the $p$ value of 0.035 .

Table 4. Diagnostic values of CDST against PCR as the gold standard.

\begin{tabular}{ccc}
\hline Statistic & Value & 95\% Confidence Interval \\
\hline Sensitivity & $85.7 \%$ & $63.7-97.0 \%$ \\
Specificity & $52.0 \%$ & $31.3-72.2 \%$ \\
Positive predictive value & $60.0 \%$ & $49.0-70.0 \%$ \\
Negative predictive value & $81.3 \%$ & $58.7-93.0 \%$ \\
Accuracy & $67.4 \%$ & $52.0-80.5 \%$ \\
\hline
\end{tabular}

\section{Discussion}

Lower respiratory tract infection (LRTI) is a well-recognized complication of artificial ventilation and is a common cause of morbidity and mortality in the ICU $[2,38]$. The snowballing frequency of the multidrug-resistant microorganisms' in ICU calls for quick and precise diagnosis of VAP, which is essential for the ideal antimicrobial intervention [5]. In the present study, quantitative culture was utilized, and it was $90 \%$ positive. The CDC (Center for Disease Control) also recommends quantitative culture methods for respiratory and VAP specimens [39]. Although another study reported that in diagnosing VAP, quantitative cultures were of limited value when utilizing endotracheal aspirates [40]. The quantitative culture of lower respiratory tract specimens obtained by non-bronchoscopic procedures is hugely beneficial in the quick diagnosis and proper therapeutic intervention of VAP [41]. There were multiple studies which showed that the high percentage of positive quantitative cultures regarding VAP patient's management [42,43].

The gender variation of the study findings was similar to another published study [44], and multiple studies reported that males were predominant suffers from $\operatorname{VAP}(46,47)$ that were in the same line of the current study [44-46]. Male predominance could be explained by the fact that Bangladesh has a large working community composed mainly of males. Multiple studies reported that among several factors, some are not changeable. These include preexisting pulmonary disease, AIDS (acquired immune deficiency syndrome), coma, head trauma, and multiple organ system failures, age of over 60 years, acute respiratory distress syndrome, chronic obstructive pulmonary disease, and male sex [47-49].

MBLs producing gram-negative bacteria were identified by the imipenem-resistant screening test in the present study, and $48.42 \%$ were imipenem-resistant. One recent Indian study reported that $28.04 \%$ were resistant to imipenem [50]. After that, the current study was higher than the study conducted in 
India [50]. Again, 65.22\% and 45.65\% imipenem-resistant MBLs were identified among the positive screening of gram-negative bacteria CDST and multiplex PCR, respectively. The earlier-mentioned Indian study reported that $70 \%$ of the imipenem-resistant gram-negative bacteria were CDST positive. Additionally, another study revealed that $65 \%$ were MBL-producers by the multiplex PCR method, which was higher than the present study [51].

The difference between CDST and PCR to detect MBL-producers was statistically significant $(p<0.05)$. CDST identified more cases of negative findings of positive imipenem than the multiplex PCR in the current study. Although CDST is a phenotypic test to detect MBL-generating organisms with the utmost sensitivity and specificity; nevertheless, multiple studies reported high false-positive results, not only for CDST but all phenotypic analysis [31,33,52,53]. Primary resistance mechanisms responsible for resistance to carbapenems is because of the production of different types of carbapenemase enzymes, namely MBL, KPC, or Oxacillinases (OXA) enzyme [17,54]. The ethylenediaminetetraacetic acid (EDTA) or MPA is utilized in CDST to possibly chelate and inhibit OXA enzymes, after that, producing a result that could be interpreted as a false-positive for the presence of MBL [55]. One Bangladeshi study reported that carbapenemase genes were spotted in $11.6 \%$ among gram-negative pathogens in urinary tract infections and entirely gram-negative microorganisms' community were carbapenemase-producing and were resistant to colistin. This study revealed that a significant rate of urinary isolates was carbapenemase producers, including a high prevalence of blaNDM-1, in Bangladesh. One Bangladeshi study reported that the carbapenemase gene, blaNDM-1, was spotted in $11.6 \%$ of gram-negative pathogens in urinary tract infections and entirely gram-negative microorganisms' community were carbapenemase-producing were and resistant to colistin [56].

One more study also reported that the presence of New Delhi metallo-B-lactamase-1 (NDM-1) producing E. coli in Bangladesh [57]. Another study conducted in a tertiary diabetic hospital situated in the capital city of Bangladesh reported that pus, blood, urine, and tracheal aspirates derived Pseudomonas isolates where the majority $(81.8 \%)$ were resistant to imipenem [58]. Clinical specimens, such as endotracheal, throat, tracheal aspirates, sputum, catheter tips, urine, pus, and wounds derived $3.5 \%$ of the gram-negative microorganisms were NDM-1 produced in Bangladesh [59]. It has been reported from the neighboring country, Burma owns three discrete $b l a_{\mathrm{NDM}}$-fostering plasmids among carbapenemase-producing Enterobacteriaceae [60]. Another Indian study conducted in neonatal ICU (NICU) utilizing a PCR-based investigation identified pathogens containing NDM-1, NDM-4, NDM-5, NDM-7, along with OXA, CMY, and SHV variants on conjugative plasmids of IncFIA, IncFIC, IncF, IncK, IncFIB, IncB/O, IncHI1, IncP, IncY, IncFIIA, IncI1, and IncN types. Subsequently, carbapenem-resistant NDM-producing Enterobacteriaceae isolates were recovered from NICU [61]. Another study revealed that carbapenemase NDM-1-producing Enterobacteriaceae is a substantial burden of public health in the Indian subcontinent [62]. One more study examined endotracheal aspirates among patients of ICU reported that $96 \%$ of Acinetobacter baumannii were multidrug-resistant. The AMR (Antimicrobial resistance) genes such as $b l a_{a m p C}$ and carbapenemase genes (bla $a_{M B L s}$ and $\left.b l a_{K P C}\right)$ were found in $95.83 \%$, and $100 \%$ of A. baumanni were cephalosporin and imipenem resistant, respectively [63]. After that, the current study showed the MBL-producing gram-negative microorganism presence through multiplex PCR among VAP patients were most likely. There are several MBL-producing genes, but the current utilizes only three $b l a_{\mathrm{NDM}}, b a_{I \mathrm{MP}}, b l a_{\mathrm{VIM}}$ genes because of financial constraints.

\section{Conclusions}

The problem of phenotypic detection of MBL by CDST is that the high false-positive reporting rate exists in the current study. So multiplex PCR is recommended for optimal detection of MBL-producers, at least in the tertiary care hospitals of Bangladesh.

\section{Recommendations}

The prevention of antimicrobial resistance in ICU patients should focus on recognition via routine unit-based surveillance, improved compliance with handwashing and barrier precautions, 
and antibiotic-use policies tailored to individual units within hospitals. Carbapenems use should be restricted. More research has been recommended in ICUs in Bangladesh to prevent AMR and to minimize the resistant microbial infection.

Author Contributions: Conceptualization, T.N., N.A.; methodology, T.N., N.A., N.A.A.R.; writing一original draft preparation, T.N., N.A., M.H.; writing-review, and editing, T.N., N.A., M.H., N.A.A.R.; supervision, T.N., N.A., M.H., N.A.A.R., A.K.D., S.A., D.T.D.R.; project administration, T.N., N.A., M.H., A.K.D., S.A. and D.T.D.R.

Funding: This research received no external funding.

Acknowledgments: The authors thank all the respected microbiologists, Lab technicians of Microbiology Department of Chattogram Medical College, Chattogram, Bangladesh, and physicians of the respected wards for contributing to carrying out the research work. Additionally, authors are much grateful to MS Razzaque, Lake Erie College of Osteopathic Medicine, 1858 West Grandview Boulevard, Erie, PA 16509, USA.

Conflicts of Interest: All the authors declare no conflict of interest.

\section{References}

1. Kalanuria, A.A.; Ziai, W.; Mirski, M. Ventilator-associated pneumonia in the ICU. Crit. Care. 2014, 18. [CrossRef] [PubMed]

2. Haque, M.; Sartelli, M.; McKimm, J.; Abu Bakar, M. Healthcare-associated infections-An overview. Infect. Drug Resist. 2018, 11, 2321-2333. [CrossRef] [PubMed]

3. Bhadade, R.; Harde, M.; De Souza, R.; More, A.; Bharmal, R. Emerging trends of nosocomial pneumonia in intensive care unit of a tertiary care public teaching hospital in Western India. Ann. Afr. Med. 2017, 16, 107-113. [CrossRef] [PubMed]

4. Hassan, Z.M.; Wahsheh, M.A. Knowledge level of nurses in Jordan on ventilator-associated pneumonia and preventive measures. Nurs. Crit. Care. 2017, 22, 125-132. [CrossRef] [PubMed]

5. Dey, A.; Bairy, I. Incidence of multidrug-resistant organisms causing ventilator-associated pneumonia in a tertiary care hospital: A nine months' prospective study. Ann. Thorac. Med. 2007, 2, 52-57. [CrossRef] [PubMed]

6. Luna, C.M.; Aruj, P.; Niederman, M.S.; Garzón, J.; Violi, D.; Prignoni, A.; Ríos, F.; Baquero, S.; Gando, S.; Grupo Argentino de Estudio de la Neumonía Asociada al Respirador Group. Appropriateness and delay to initiate therapy in ventilator-associated pneumonia. Eur. Respir. 2006, 27, 158-164. [CrossRef] [PubMed]

7. Scholte, J.B.; van Dessel, H.A.; Linssen, C.F.; Bergmans, D.C.; Savelkoul, P.H.; Roekaerts, P.M.; van Mook, W.N. Endotracheal aspirate and bronchoalveolar lavage fluid analysis: Interchangeable diagnostic modalities in suspected ventilator-associated pneumonia? J. Clin. Microbiol. 2014, 52, 3597-3604. [CrossRef] [PubMed]

8. Khilnani, G.C.; Arafath, T.K.; Hadda, V.; Kapil, A.; Sood, S.; Sharma, S.K. Comparison of bronchoscopic and non-bronchoscopic techniques for diagnosis of ventilator-associated pneumonia. Indian J. Crit. Care Med. 2011, 15. [CrossRef]

9. Koenig, S.M.; Truwit, J.D. Ventilator-associated pneumonia: Diagnosis, treatment, and prevention. Clin. Microbiol. Rev. 2006, 19, 637-657. [CrossRef]

10. Shin, Y.M.; Oh, Y.M.; Kim, M.N.; Shim, T.S.; Lim, C.M.; Lee, S.D.; Koh, Y.; Kim, W.S.; Kim, D.S.; Hong, S.B. Usefulness of quantitative endotracheal aspirate cultures in intensive care unit patients with suspected pneumonia. J. Korean Med. Sci. 2011, 26, 865-869. [CrossRef]

11. Zaccard, C.R.; Schell, R.F.; Spiegel, C.A. Efficacy of bilateral bronchoalveolar lavage for diagnosis of ventilator-associated pneumonia. J. Clin. Microbiol. 2009, 47, 2918-2924. [CrossRef]

12. Prats, E.; Dorca, J.; Pujol, M.; Garcia, L.; Barreiro, B.; Verdaguer, R.; Gudiol, F.; Manresa, F. Endotracheal aspirate, and bronchoalveolar lavage fluid analysis: Interchangeable diagnostic modalities in suspected ventilator-associated pneumonia? Eur. Respir. J. 2002, 19, 944-951. [CrossRef]

13. Li, Y.; Gong, Z.; Lu, Y.; Hu, G.; Cai, R.; Chen, Z. Impact of nosocomial infections surveillance on nosocomial infection rates: A systematic review. Int. J. Surg. 2017, 42, 164-169. [CrossRef] [PubMed]

14. McCann, E.; Srinivasan, A.; De Ryke, C.A.; Gang, Y.; DePestel, D.D.; Murray, J.; Gupta, V. Carbapenemnonsusceptible gram-negative pathogens in ICU and non-ICU settings in US hospitals in 2017: A Multicenter Study. Open Forum Infect. Dis. 2018, 5, ofy241. [CrossRef] [PubMed] 
15. Porwal, R.; Gopalakrishnan, R.; Rajesh, N.J.; Ramasubramanian, V. Carbapenem-resistant gram-negative bacteremia in an Indian intensive care unit: A review of the clinical profile and treatment outcome of 50 patients. Indian J. Crit. Care Med. 2014, 18, 750-753. [CrossRef] [PubMed]

16. Dortet, L.; Poirel, L.; Nordmann, P. Worldwide dissemination of the NDM-type carbapenemases in gram-negative bacteria. Biomed. Res. Int. 2014. [CrossRef] [PubMed]

17. Codjoe, F.S.; Donkor, E.S. Carbapenem resistance: A review. Med. Sci. 2017, 6. [CrossRef]

18. Petersen-Morfin, S.; Bocanegra-Ibarias, P.; Morfin-Otero, R.; Garza-Gonzales, E.; Perez-Gomez, H.R.; Gonzales-Diaz, E.; Esparza-Ahumada, S.; León-Garnica, G.; Amezcua-Salazar, G.; Rodriguez-Noriega, E. New Delhi metallo-beta-lactamase (NDM-1)-producing klebsiella pneumoniae isolated from a burned patient. Am. J. Case Rep. 2017, 18, 805-809. [CrossRef]

19. Caliendo, A.M.; Gilbert, D.N.; Ginocchio, C.C.; Hanson, K.E.; May, L.; Quinn, T.C.; Tenover, F.C.; Alland, D.; Blaschke, A.J.; Bonomo, R.A.; et al. Better tests, better care: Improved diagnostics for infectious diseases. Clin. Infect. Dis. 2013, 57, S139-S170. [CrossRef]

20. Aydemir, O.; Aydemir, Y.; Ozdemir, M. The role of multiplex PCR test in identification of bacterial pathogens in lower respiratory tract infections. Pak. J. Med. Sci. 2014, 30, 1011-1016. [CrossRef]

21. Dogonchi, A.A.; Ghaemi, E.A.; Ardebili, A.; Yazdansetad, S.; Pournajaf, A. Metallo- $\beta$-lactamase-mediated resistance among clinical carbapenem-resistant Pseudomonas aeruginosa isolates in northern Iran: A potential threat to clinical therapeutics. Ci Ji Yi Xue Za Zhi 2018, 30, 90-96. [CrossRef] [PubMed]

22. Lund, M.; Petersen, M.B.; Jørgensen, A.L.; Paulmann, D.; Wang, M. Rapid real-time PCR for the detection of IMP, NDM, VIM, KPC and OXA-48 carbapenemase genes in isolates and spiked stool samples. Diagn. Microbiol. Infect. Dis. 2018, 92, 8-12. [CrossRef] [PubMed]

23. Fallah, F.; Borhan, R.S.; Hashemi, A. Detection of bla (IMP) and bla (VIM) metallo- $\beta$-lactamases genes among Pseudomonas aeruginosa strains. Int. J. Burns Trauma 2013, 3, 122-124. [PubMed]

24. Hong, D.J.; Bae, I.K.; Jang, I.H.; Jeong, S.H.; Kang, H.K.; Lee, K. Epidemiology and characteristics of metallo- $\beta$-lactamase-producing Pseudomonas aeruginosa. Infect. Chemother. 2015, 47, 81-97. [CrossRef] [PubMed]

25. Craven, D.E.; Chroneou, A.; Zias, N.; Hjalmarson, K.I. Ventilator-associated tracheobronchitis: The impact of targeted antibiotic therapy on patient outcomes. Chest 2009, 135, 521-528. [CrossRef] [PubMed]

26. Medcalculator, Free Statistical Calculator: Diagnostic Test Evaluation Calculator. Available online: https: //www.medcalc.org/calc/diagnostic_test.php (accessed on 30 August 2019).

27. Ali, S.Q.; Zehra, A.; Naqvi, B.S.; Shah, S.; Bushra, R. Resistance pattern of ciprofloxacin against different pathogens. Oman. Med. J. 2010, 25, 294-298. [CrossRef] [PubMed]

28. CLSI. Performance Standards for Antimicrobial Disk Susceptibility Tests, 29th ed.; CLSI Supplement M100: Wayne, PA, USA, 2019.

29. Jing, X.; Zhou, H.; Min, X.; Zhang, X.; Yang, Q.; Du, S.; Li, Y.; Yu, F.; Jia, M.; Zhan, Y. The simplified carbapenem inactivation method (sCIM) for simple and accurate detection of carbapenemase-producing gram-negative bacilli. Front. Microbiol. 2018, 9, 2391. [CrossRef] [PubMed]

30. Hodiwala, A.; Dhoke, R.; Urhekar, A.D. Incidence of mettalo-beta-lactamase producing pseudomonas, Acinetobacter \& enterobacterial isolates in hospitalized patients. IJPBS. 2013, 3, 79-83.

31. Khosravi, Y.; Loke, M.; Chua, E.G.; Tay, S.T.; Vadivelu, J. Phenotypic detection of metallo- $\beta$-lactamase in imipenem-resistant Pseudomonas aeruginosa. Sci. World J. 2012. [CrossRef]

32. Yong, D.; Lee, K.; Yum, J.H.; Shin, H.B.; Rossolini, G.M.; Chong, Y. Imipenem-EDTA disk method for differentiation of metallo-beta-lactamase-producing clinical isolates of Pseudomonas spp. and Acinetobacter spp. J. Clin. Microbiol. 2002, 40, 3798-3801. [CrossRef]

33. Sachdeva, R.; Sharma, B.; Sharma, R. Evaluation of different phenotypic tests for detection of metallo- $\beta$-lactamases in imipenem-resistant Pseudomonas aeruginosa. J. Lab. Physicians. 2017, 9, $249-253$. [CrossRef] [PubMed]

34. Mehta, A.; Prabhu, T. Detection and characterization of metallo- $\beta$-lactamases producing Pseudomonas aeruginosa clinical isolates at a tertiary care. Int. J. Res. Med. Sci. 2016, 4, 4084-4088. [CrossRef]

35. Mohanam, L.; Menon, T. Coexistence of metallo-beta-lactamase-encoding genes in Pseudomonas aeruginosa. Indian J. Med. Res. 2017, 146, S46-S52. [CrossRef] [PubMed] 
36. Mishra, S.; Upadhyay, S.; Sen, M.R.; Maurya, A.P.; Choudhury, D.; Bhattacharjee, A. Genetic acquisition of NDM gene offers sustainability among clinical isolates of Pseudomonas aeruginosa in clinical settings. PLoS ONE 2015, 10, e0116611. [CrossRef] [PubMed]

37. Joshi, P.R.; Achariya, M.; Lalshaptai, T.; Leungtong, U.; Thummeepak, R.; Sitthisak, S. Co-existence of blaOXA -23 and blaNDM -1 gene of Acinetobacter baumannii isolated from Nepal: Antimicrobial resistance and clinical significance. Antimicrob. Resist. Infect. Control 2017, 6, 1-13. [CrossRef] [PubMed]

38. Feldman, C.; Richards, G. Appropriate antibiotic management of bacterial lower respiratory tract infections. F1000 Res. 2018, 7. [CrossRef] [PubMed]

39. Baselski, V.; Klutts, J.S.; Baselski, V.; Klutts, J.S. Quantitative cultures of bronchoscopically obtained specimens should be performed for optimal management of ventilator-associated pneumonia. J. Clin. Microbiol. 2013, 51, 740-744. [CrossRef] [PubMed]

40. Jourdain, B.; Novara, A.; Joly-Guillou, M.L.; Dombret, M.C.; Calvat, S.; Trouillet, J.L.; Gibert, C.; Chastre, J. Role of quantitative cultures of endotracheal aspirates in the diagnosis of nosocomial pneumonia. Am. J. Respir. Crit. Care Med. 1995, 152, 241-246. [CrossRef]

41. Pugain, J.; Auckenthaler, R.; Mili, N.; Janssens, J.P.; Lew, P.D.; Suter, P.M. Diagnosis of ventilator-associated pneumonia by bacteriologic analysis of bronchoscopic and nonbronchoscopic blind bronchoalveolar lavage fluid. Am. Rev. Respir. Dis. 1991, 143, 1121-1129. [CrossRef]

42. Rajasekhar, T.; Anuradha, K.; Suhasini, T.; Lakshmi, V. The role of quantitative cultures of non-bronchoscopic samples in ventilator-associated pneumonia. Indian J. Med. Microbiol. 2006, 24, 107-113.

43. Azarudeen, M.; Sharma, B.S.; Jain, P.K.; Goyal, A.K.; Malhotra, B. Study of quantitative bacterial cultures of non-bronchoscopic samples in ventilator-associated pneumonia. Int. J. Contemp. Pediatr. 2018, 5, 1837-1843. [CrossRef]

44. Lipovy, B.; Rihová, H.; Gregorova, N.; Hanslianova, M.; Zaloudikova, Z.; Kaloudova, Y.; Brychta, P. Epidemiology of ventilator-associated Tracheobronchitis and ventilator pneumonia in patients with inhalation injury at a burn center in Brno (Czech Republic). Ann. Burns Fire Disasters 2011, 24, 120-125. [PubMed]

45. Goel, V.; Hogade, S.A.; Karadesai, S. Ventilator-associated pneumonia in a medical intensive care unit: Microbial etiology, susceptibility patterns of isolated microorganisms and outcome. Indian J. Anaesth. 2012, 56, 558-562. [CrossRef] [PubMed]

46. Ranjan, N.; Chaudhary, U.; Chaudhry, D.; Ranjan, K.P. Ventilator-associated pneumonia in a tertiary care intensive care unit: Analysis of incidence, risk factors, and mortality. Indian J. Crit. Care Med. 2014, 18, 200-204. [CrossRef] [PubMed]

47. Bonten, M.J.; Kollef, M.H.; Hall, J.B. Risk factors for ventilator-associated pneumonia: From epidemiology to patient management. Clin. Infect. Dis. 2004, 38, 1141-1149. [CrossRef] [PubMed]

48. Arumugam, S.K.; Mudali, I.; Strandvik, G.; El-Menyar, A.; Al-Hassani, A.; Al-Thani, H. Risk factors for ventilator-associated pneumonia in trauma patients: A descriptive analysis. World J. Emerg. Med. 2018, 9, 203-210. [CrossRef] [PubMed]

49. Ali, H.S.; Khan, F.Y.; George, S.; Shaikh, N.; Al-Ajmi, J. Epidemiology and outcome of ventilator-associated Pneumonia in a heterogeneous ICU population in Qatar. Biomed Res. Int. 2016, 8231787. [CrossRef] [PubMed]

50. Panchal, C.A.; Oza, S.S.; Mehta, S.J. Comparison of four phenotypic methods for detection of metallo- $\beta$-lactamase-producing Gram-negative bacteria in rural teaching hospital. J. Lab. Physicians 2017, 9, 81-83. [CrossRef] [PubMed]

51. Solanki, R.; Vanjari, L.; Subramanian, S.; Aparna, B.; Nagapriyanka, E.; Vemu, L. Comparative evaluation of multiplex PCR and routine laboratory phenotypic methods for detection of Carbapenemases among gram-negative bacilli. J. Clin. Diagn. Resp. 2014, 8, 23-26.

52. Picão, R.C.; Andrade, S.S.; Nicoletti, A.G. Metallo-beta-lactamase detection: Comparative evaluation of double-disk synergy versus combined disk tests for IMP-, GIM-, SIM-, SPM-, or VIM-producing isolates. J. Clin. Microbiol. 2008, 46, 2028-2037. [CrossRef] [PubMed]

53. Ranjan, S.; Banashankari, G.S.; Babu, P.R. Evaluation of phenotypic tests and screening markers for detection of metallo- $\beta$-lactamases in clinical isolates of Pseudomonas aeruginosa: A prospective study. Med. J. DY Patil Univ. 2015, 8, 599-605. [CrossRef]

54. Meletis, G.; Exindari, M.; Vavatsi, N.; Sofianou, D.; Diza, E. Mechanisms responsible for the emergence of carbapenem resistance in Pseudomonas aeruginosa. Hippokratia 2012, 16, 303-307. [PubMed] 
55. Martins, A.F.; Borges, A.; Pagano, M.; Dalla-Costa, L.M.; Barth, A.L. False-positive results in screening for metallo- $\beta$-lactamase are observed in isolates of Acinetobacter baumannii due to production of Oxacillinases. Braz. J. Infect. Dis. 2013, 17, 500-501. [CrossRef] [PubMed]

56. Begum, N.; Shamsuzzaman, S.M. Emergence of carbapenemase-producing urinary isolates at a tertiary care hospital in Dhaka, Bangladesh. Ci Ji Yi Xue Za Zhi 2016, 28, 94-98. [CrossRef] [PubMed]

57. Poirel, L.; Lagrutta, E.; Taylor, P.; Pham, J.; Nordmann, P. Emergence of metallo- $\beta$-lactamase NDM-1-producing multidrug-resistant Escherichia coli in Australia. Antimicrob. Agents Chemother. 2010, 54, 4914-4916. [CrossRef] [PubMed]

58. Nasrin, T.; Jilani, M.S.A.; Barai, L.; Haq, J.A. Metallo-ß-lactamase producing Pseudomonas species in a tertiary care hospital of Dhaka City. Bangladesh J. Med. Microbiol. 2010, 4, 43-45. [CrossRef]

59. Islam, M.A.; Talukdar, P.K.; Hoque, A.; Huq, M.; Nabi, A.; Ahmed, D.; Talukder, K.A.; Pietroni, M.A.; Hays, J.P.; Cravioto, A.; et al. Emergence of multidrug-resistant NDM-1-producing gram-negative bacteria in Bangladesh. Eur. J. Clin. Microbiol. Infect. Dis. 2012, 31, 2593-2600. [CrossRef] [PubMed]

60. Sugawara, Y.; Akeda, Y.; Hagiya, H.; Sakamoto, N.; Takeuchi, D.; Shanmugakani, R.K.; Motooka, D.; Nishi, I.; Zin, K.N.; Aye, M.M.; et al. Spreading patterns of NDM-producing enterobacteriaceae in clinical and environmental settings in Yangon, Myanmar. Antimicrob. Agents Chemother. 2019, 63. [CrossRef]

61. Ahmad, N.; Khalid, S.; Ali, S.M.; Khan, A.U. Occurrence of $b l a_{\mathrm{NDM}}$ variants among enterobacteriaceae from a neonatal intensive care unit in a Northern India hospital. Front Microbiol. 2018, 9, 407. [CrossRef] [PubMed]

62. Kumarasamy, K.K.; Toleman, M.A.; Walsh, T.R.; Bagaria, J.; Butt, F.; Balakrishnan, R.; Chaudhary, U.; Doumith, M.; Giske, C.G.; Irfan, S.; et al. Emergence of a new antibiotic resistance mechanism in India, Pakistan, and the UK: A molecular, biological, and epidemiological study. Lancet Infect. Dis. 2010, 10, 597-602. [CrossRef]

63. Khatun, M.N.; Farzana, R.; Lopes, B.S.; Shamsuzzaman, S.M. Molecular characterization and resistance profile of nosocomial Acinetobacter baumannii in intensive care unit of tertiary care hospital in Bangladesh. Bangladesh Med. Res. Counc. Bull. 2015, 41, 101-107. [CrossRef] [PubMed]

(C) 2019 by the authors. Licensee MDPI, Basel, Switzerland. This article is an open access article distributed under the terms and conditions of the Creative Commons Attribution (CC BY) license (http://creativecommons.org/licenses/by/4.0/). 